\title{
Psychometric Properties for Well-being: Developing and Validating Happiness Instrument
}

\author{
Ateerah A.R. ${ }^{1}$, Lukman, Z.M. ${ }^{2}$, Amanina, A.R ${ }^{3}$ \\ ${ }^{1}$ University of Malaysia Kelantan, Malaysia. \\ ${ }^{2}$ University of Sultan Zainal Abidin, Terengganu. \\ ${ }^{3}$ MARA University of Technology, Kelantan Branch. \\ ateerah@umk.edu.my, lukmanzm@hotmail.com, amanina81@uitm.edu.my
}

\begin{abstract}
There are various factors that make human beings feel happy, one of them is possessing a good psychological well-being that they had. The purpose of this study was to identify an element of happiness that fulfil human's necessity in their life, then develop the happiness measurement to an appropriate instrument. This research was conducted in different states in Malaysia using a survey method with quantitative approach. The number of samples of about 475 Malaysian from various stages of age using the purposive sampling technique. Data of happiness instrument was obtained through Al-Ghazali's concept of happiness which includes religious knowledge, righteous practices and individual aspect and they act as the independent variables. Meanwhile, happiness itself acts as the dependent variable. The findings were then analysed using SPSS and PLS. Based on the structural equation modelling, the study found that religious knowledge, practices, and individual constructs have significant relationship with happiness. The average variance extracted (AVE) values ranges between 0.5010 .615 , which is an acceptable valid range. It can be observed that there is a significant relation between individual construct and happiness $(\mathrm{t}=2.817, \mathrm{p}<0.005)$, practices and happiness $(\mathrm{t}=6.805$, $\mathrm{p}<0.000)$, and religious knowledge and happiness $(\mathrm{t}=3.947, \mathrm{p}<0.000)$. Moreover, the positive sign implies that there is a direct relationship between the dependent and independent variables.
\end{abstract}

\section{Introduction}

Happiness and well-being are frequently described as internal feelings or states of satisfaction that reside internally within the individual [1]. There is a wealth of studies and an increase in research concerning happiness $[2,3,4]$. However, there are still lacking in studies about its psychometric properties based on Islamic perspective. The sources to measure Muslim's daily practices based on Islamic rules and practices are still limited [5]. It is mentioned that an appropriate scale of well-being for Muslim so that they have secured happiness in the afterlife seems to be necessary to be included in future research [6]. Despite the fact that studies on mental health have grown, but most of them focus on the western population only [7].

Islamic view of happiness closely relates and focuses on the peacefulness of heart, tranquillity and certainty [8]. The Quran also stresses on the aspect of God remembrance (dhikr) that leads to one's happiness and it denotes to holding knowledge in the mind, and this knowledge relates to the oneness of Allah (tauhid) [9]. Additionally, righteousness is one of the indicators of Muslim happiness. It is in line with the theory of psychology in Islam that emphasises the significant function of heart of which 


\section{Kresna Social Science and Humanities Research}

Proceedings of the International Conference On Ummah:

Digital Innovation, Humanities And Economy (ICU: DIHEc) 2020

https://doi.10.30874/ksshr.34

attaining happiness when it is able to receive guidance. Moreover, it is the centre of human personality, and also the meeting point with Allah [10]. The perceived concept of happiness in Islam is that it is a feeling that exists in the heart. It is characterised by peace of mind, a sense of well-being and tranquillity and a relaxed attitude. It appears because of good characteristic, both inward and outward and is guided by strong faith [11].

According to Al-Ghazali, knowledge and practice are resulted from the condition of the good soul and without these, it is difficult to attain happiness. As for knowledge, it refers to the knowledge about Allah and the path to Him. The knowledge as the main tool to purify the soul [12] and acts as a contributor of happiness, due to the fact that soul purification leads to happiness [13]. He further describes in about the knowledge of four aspects in the metamorphosis that changes a person from animal into an angel [14].

The elements of religious knowledge in this study are Knowledge of Self; the quality of being able to recognise self-roles towards Allah and other's creation, Knowledge about Allah; the ability of someone to realise Allah's omnipotent and have a sense of fear towards Allah, Knowledge of the World; the capability of someone to be aware of the enchanting of the world and ensure to protect himself (physically and spiritually) from sins and Knowledge of the Hereafter; knowledge of hereafter refers to the competency of someone to know the unseen elements (i.e. soul) and the preparation to face the hereafter.

Meanwhile practice is defined as constantly doing righteous inward and outward actions in order to gain eternal happiness as guided in Islam. This rule for practices is described as a balanced action ('amal). It relates to the element of practical on the methods to do good actions. It also has two elements namely action pertains to the practical aspect of how to perform good deeds.

For individual aspect, it connects to external aspects for human which encompasses several elements such as physical health, long life and appearance. In the current study, individual refers to the humans' perception about the physical aspects which lead them to attain happiness whereas social relationship act as impact of happiness, in which it is stated that instead of knowing the secret of attaining Allah's happiness, man should possess good demeanour and also become appealing to other people and behave in society, thus it will ensure him to gain happiness. It denotes a pleasant and good networking towards human being. Based on the description above, this study has developed several constructs and items to measure happiness, then validate it using EFA and CFA.

\section{Method}

This research is a survey research, using descriptive statistical analysis to obtain valid items and suitable to be used to measure happiness of Muslim. The items have been constructed and revised after final agreement with the panels and supervisors. After that, it was submitted to the supervisory committee so that they can analyse for modification proposed to ensure that it matches the goal in the field of this study. The content validity was endorsed by nine experts who were chosen according to their experiences in certain research field. The panellists are Professors in Islamic Psychology, Hadith Studies, Islamic Social Development, Cognitive Behavior Study, Measurement and Statistics.

This study was conducted in a few states in Malaysia namely Kelantan, Melaka, Perlis and Selangor. The time of data collection was about two months. The research sample was taken by means of purposive sampling with the criteria; age between 18-75 and literate Muslim.

\section{Results and Discussion}

Based on the data processing, it has significant relationship between independent and dependent variables. The complete results of each construct can be seen in the table 1: 


\section{Kresna Social Science and Humanities Research}

Proceedings of the International Conference On Ummah:

Digital Innovation, Humanities And Economy (ICU: DIHEc) 2020

https://doi.10.30874/ksshr.34

Table 4.12: Average of Construct

\begin{tabular}{lcc}
\hline \multicolumn{1}{c}{ Construct } & Mean & SD \\
\hline Knowledge of Self & 3.84 & 0.76 \\
Knowledge of Allah & 3.99 & 0.65 \\
Knowledge of world & 3.99 & 0.65 \\
Knowledge of hereafter & 3.98 & 0.60 \\
Soul Purification practices & 3.85 & 0.62 \\
Individual & 3.98 & 0.60 \\
Happiness (Social Relationship) & 3.92 & 0.61
\end{tabular}

For the main construct of Religious Knowledge, Knowledge of Self has attained a mean of $3.84 \pm 0.76$, Knowledge of Allah has attained a mean of (3.99 \pm 0.65$)$, Knowledge of the World (3.99 \pm 0.65$)$, and Knowledge of the Hereafter, which has attained a mean of 3.98 \pm 0.60 , and it is evident that most of the participants agree with the sub-construct. Coherently, the construct of Soul Purification Practices has attained a mean of $3.85 \pm 0.62$, Individual construct has attained a mean of $3.98 \pm 0.60$, and it means that most of the respondents agree with the latter construct. For the construct of happiness which is measured by Social Relationship aspect, the mean accumulates 3.92 \pm 0.61 denotes that respondents agree with the construct. Detail values of items are depicted in the Table 2.

\begin{tabular}{|c|c|c|c|c|}
\hline Constructs & Outer Loading & CA & $\mathrm{CR}$ & AVE \\
\hline \multicolumn{5}{|c|}{ RELIGIOUS KNOWLEDGE } \\
\hline Knowledge of self & & 0.85 & 0.878 & 0.508 \\
\hline b1_10 & 0.798 & & & \\
\hline b1_4 & 0.633 & & & \\
\hline b1_5 & 0.705 & & & \\
\hline b1_6 & 0.648 & & & \\
\hline b1_7 & 0.678 & & & \\
\hline b1_8 & 0.731 & & & \\
\hline b1_9 & 0.781 & & & \\
\hline Knowledge of god & & 0.85 & 0.887 & 0.531 \\
\hline b2_3 & 0.579 & & & \\
\hline b2_4 & 0.715 & & & \\
\hline b2_5 & 0.701 & & & \\
\hline b2_6 & 0.715 & & & \\
\hline b2_7 & 0.811 & & & \\
\hline b2_8 & 0.787 & & & \\
\hline b2_9 & 0.768 & & & \\
\hline Knowledge of world & & 0.835 & 0.877 & 0.51 \\
\hline b3_10 & 0.75 & & & \\
\hline b3_2 & 0.544 & & & \\
\hline b3_5 & 0.76 & & & \\
\hline b3_6 & 0.861 & & & \\
\hline b3_7 & 0.64 & & & \\
\hline b3_8 & 0.678 & & & \\
\hline b3_9 & 0.723 & & & \\
\hline Knowledge of hereafter & & 0.877 & 0.905 & 0.576 \\
\hline b4_10 & 0.717 & & & \\
\hline b4_3 & 0.727 & & & \\
\hline b4_4 & 0.782 & & & \\
\hline b4_5 & 0.771 & & & \\
\hline b4_6 & 0.754 & & & \\
\hline b4_7 & 0.769 & & & \\
\hline
\end{tabular}




\section{Kresna Social Science and Humanities Research}

Proceedings of the International Conference On Ummah:

Digital Innovation, Humanities And Economy (ICU: DIHEc) 2020 https://doi.10.30874/ksshr.34

\begin{tabular}{|c|c|c|c|c|}
\hline $\begin{array}{l}\text { b4_8 } \\
\text { PRACTICE }\end{array}$ & 0.789 & & & \\
\hline Soul Purification & & 0.843 & 0.881 & 0.516 \\
\hline c2 2 gate & 0.694 & & & \\
\hline c3 & 0.744 & & & \\
\hline c4 & 0.766 & & & \\
\hline c5 & 0.769 & & & \\
\hline c6 & 0.747 & & & \\
\hline c7 & 0.668 & & & \\
\hline c8 & 0.63 & & & \\
\hline INDIVIDUAL & & 0.874 & 0.905 & 0.615 \\
\hline $\mathrm{d} 1$ & 0.804 & & & \\
\hline $\mathrm{d} 10$ & 0.809 & & & \\
\hline $\mathrm{d} 2$ & 0.722 & & & \\
\hline d6 & 0.778 & & & \\
\hline d7 & 0.786 & & & \\
\hline d9 & 0.802 & & & \\
\hline HAPPINESS & & 0.833 & 0.875 & 0.501 \\
\hline $\mathrm{e} 1$ & 0.656 & & & \\
\hline e10 & 0.687 & & & \\
\hline $\mathrm{e} 2$ & 0.708 & & & \\
\hline e3 & 0.723 & & & \\
\hline e7 & 0.758 & & & \\
\hline e8 & 0.68 & & & \\
\hline e9 & 0.736 & & & \\
\hline
\end{tabular}

Based on the table, the first strongest item according to knowledge of Self in the construct of Religious Knowledge is item (10); Humans need to use the aqal well to avoid doing negative things. 'Aqal is used to make rational decision, in accordance with religious rules. Human who uses 'aqal properly will attain happiness in the world and hereafter. Scientifically, it is also proven that some of human emotions are conscious and non-conscious that affect our thinking, however rational thinking and human emotions need to be controlled to produce good result in any action [15].

The second strongest item is item (9); Humans have to be responsible for all the actions taken. The individual must be responsible for every action done because it will determine their level of happiness $[16,17]$. Research relates to responsible attitudes showing that the characteristic is needed in order to produce sustainability of the environment [18]. The weakest item is item (4); The heart will be atpeace once humans get to know the creator. Thus, this process will enable humans to know the superiority of Allah [19]. The second weakest item is item (6); The purpose of human creation is to serve Allah. The action of eschewing the worldly pleasure and questing happiness in the hereafter is essential for a Muslim who aims to serve his religion and for the victory of Islam, and that is the totality of the subservience of a human [20]. Additionally, the Quran also elaborates the way to gain happiness in which it derives from the creator of humanity itself [21].

Meanwhile, the highest item from the construct of knowledge of Allah is item (4); Allah's blessings surpass His torments. Happiness is attained by following what the Prophet has said and that the individual also would be able to win Allah's pleasure as well as escape his punishment [22]. The second strongest item is item (5); Allah is the one who gives prosperity (rezeki) to all His servants. This is due to the fact that these predicaments have a strong relationship with inequality of wealth and resources [23]. The second weakest item is item (3); Allah's power is infinite everywhere. Islam emphasises this, in which power in the hands of a human is not absolute, and cannot be applied merely to fulfil the human's desire; the ultimate power is belonged to Allah [24]. It is also essential to comprehend the attributes of Allah via the right interpretation which is in line with the principle of the al-Quran and 


\section{Kresna Social Science and Humanities Research}

Proceedings of the International Conference On Ummah:

Digital Innovation, Humanities And Economy (ICU: DIHEc) 2020 https://doi.10.30874/ksshr.34

Sunnah and leads a Muslim to hold with the right belief (i'tiqad) [25]. However, the weakest item is item (6); Allah has set out that every good deed a human does is for his own benefit. Similarly, in the recent study, the act of righteous deeds also has been revealed as a contributor of individual happiness [26].

Apart from that, as for the construct of knowledge of the world, the strongest item is item (5); This world is created for various purposes. Every individual should cultivate their inner self in order to pursue happiness in this troubled world [27]. Then, the second strongest item is item (10); Humans depend on each other to fulfil their daily needs. It also refers to the similar findings of Greco \& Ison (2014) who state that family and friendship are the primary source of happiness [28]. On the contrary, the second weakest item is item (7); Humans can enjoy the world's beauty as long as they live. It is permittable to live happily as long as they abide by Islamic rules, and happiness is also a term for a good life [29], subjective well-being [30] and it has a wide concept which connects to the psychological and physical condition, as well as social and environmental aspects [31].

Meanwhile, the weakest item is item number two (2); This world is like a prison for the believers (mukmin), and a heaven for the irreligious (kufur). This indicates that Islam has its certain rules for Muslims to make sure they gain happiness in this world and the hereafter. Similarly, Christians' view of the hell and paradise concept is that they categorise the hell as the place to lose the happiness and joy, whereas the paradise is a reward and deserved for virtuous people [32].

Additionally, from the construct of knowledge of hereafter, the strongest item falls on item (8); Humans need to sacrifice the worldly interests just to earn the happiness in the Hereafter. Likewise, the concept of asceticism (zuhd) is a part of soul purification which leads the individual to attain ultimate happiness. Hence, the human should know how to liberate himself from anything that would distract him towards worldly desire [33]. Next, the second strongest item is item (4); The heart that is filled with love towards Allah will feel the closeness (muraqabah) to Allah. Muraqabah refers to the practice among sufism and it is a continual process to instil the certainty towards the believers, so that they will get to know Allah as the Creator [34], and this also contributes to Muslim happiness. Then, the second weakest item is item (3); The heart that is filled with love towards Allah will manage to escape all the worldly needs. Al-Kirmani (2007) states that the ultimate happiness could be reached when he reunites with his beloved [35]. Real happiness could be measured in a soul condition whereby it connects to the afterlife [36], in a condition that the person is able to detach himself from worldly desire. On top of that, the weakest item is item (10); Humans need to realise that whatever they possess in this world will be left behind once they are in the Hereafter. This shows that our possessions do not affect the happiness level due to the fact that in the end, the happiness measurement will be the same [37].

For the construct of soul purification practice, the strongest item for soul purification is item (5); I fast in the month of Ramadan. The findings of Steptoe (2018) also reveals that dietary choice influences the happiness level [38], and it promotes Muslim well-being [39] which then assists them to achieve self-happiness. This practice is combined by several soul purification practices, for example item (4); Reciting dhikr every morning and evening constantly, and this will ensure happiness in Muslims' life. Additionally, the practice of the remembrance of Allah acts as one of the religious strategies to handle with stressors [40]. The second weakest item is item (7); I am always patient in facing any misfortune. A previous study on attitudes of a peaceful and happy life mentions that the concept of peace and happiness have slightly dissimilar definitions, but they affect each other and the characteristics and the resemblances produce a very positive well-being [41]. It seems that the practice of patience leads to the growth of Muslim well-being [42]. The weakest item is item (8); I am always grateful with all the blessings that Allah has given me. Research has been conducted among Americans and Koreans and they revealed that expressing gratitude increases individual happiness [43]. Likewise, the practice of thankfulness could assist the person to cope with stress [44].

The strongest item in the construct of individual happiness is item (7) The belief of the individual that whatever they have will be taken back. Even though it has been agreed among religions and philosophers that money could not buy happiness, however, many people view the elements differently 


\section{Kresna Social Science and Humanities Research}

Proceedings of the International Conference On Ummah:

Digital Innovation, Humanities And Economy (ICU: DIHEc) 2020 https://doi.10.30874/ksshr.34

[45]. Besides, it has been proved that a materialistic lifestyle is associated with a demolished subjective well-being [46]. Nevertheless, people still pursue material things rather than questing for sustainable well-being. This shows that people who apply the concept of impermanent wealth having nothing to do with real happiness will achieve both; happiness in the world as well as the hereafter.

Apart from that, the second strongest item is item (10); The beauty aspect. Studies also prove that individual beauty increases happiness. Findings of Hamermesh \& Abrevaya (2011) show that most of the respondents mentioned that beauty could improve salary and relationships [47]. This shows that the effect of beauty towards happiness is slightly linked. Likewise, this study also shows that female respondents are more sensitive with the statements. That is to show the nature of the human-being and they assume the element is important to achieve worldly happiness. Subsequently, the weakest item is item (2); Born in a well-to-do family. According to Al-Ghazali, this wealth aspect is important so that the people will use their wealth in a proper way to gain happiness in the world and the hereafter. This statement also shows the agreement among the respondents even though it is the weakest item among the measurements of individual happiness. This is also parallel with the Islamic requirement in which a Muslim is regarded as happy when he obeys Allah, even if it does not assist him to in gaining more material wealth [48]. Then, the weakest item is item (6); Someone does not measure himself based on status and position. Even though the measurement of individual well-being also relates to increment of his position into a better one [49], but we are not encouraged to standardise human happiness with whom they are. This indicates that rich and poor people need to receive the same treatment.

For the strongest item in social relationship which is a measurement of happiness is item (7); I fulfil all my responsibilities towards the society without any self-interest. These people will be granted happiness because they have a good soul which cause them to perform righteous deeds towards the society. Similarly, Asians also associate happiness with harmonious social relationships [50] and free from selfishness. A study on individual happiness clarifies that a compassionate deed done to others is one of the indicators that agreed upon world's happiest human-being [51]. Additionally, the second strongest item is item (9); I manage to make sure that my family does not neglect Allah. The prohibition is in order to make sure Muslims would perform their responsibilities properly especially towards their families. In western perspective, good communication among family members is an important aspect to realise family happiness [52]. The weakest item is item (8) Showing good example to society. This is also parallel with the findings of Layous et al., (2013) who mention that the act of kindness escalates the happiness level [53]. Apart from that, the second weakest item is item (1); I interact well and exhibit good characters towards people. A person who is more spiritual is discovered to be happier as he/she feels close with surrounding people and is always searching for harmony and peace in everything [54]. The element of social relationship is very important because Islam encourages people to have a good relationship with Allah and also with society so that they will get Allah's blessing with happiness in the world and hereafter.

\section{Conclusion}

Based on the results of the research described above, happiness instrument can assist Muslims in gauging the level of happiness and provides the way for better and more precise instrument for evaluating happiness from the Islamic perspective in the future. The well-being of humankind and populations can be evaluated objectively or subjectively [55]. The findings of the analysis on religious knowledge and practices as contributors are congruent with a number of scientific studies that considered religious knowledge [56, 57], practices $[58,59]$ and individual happiness as some of the factors of happiness in accordance with the theory. These findings indicated that possessing religious knowledge and righteous practices are a guidance of making people, specifically Muslims to be happy in the world and the hereafter. 


\section{Kresna Social Science and Humanities Research}

Proceedings of the International Conference On Ummah:

Digital Innovation, Humanities And Economy (ICU: DIHEc) 2020 https://doi.10.30874/ksshr.34

\section{References}

[1] Yukiko, U. Oishi, S. (2016). The Happiness of Individuals and the Collective. Japanese Psychological Research 58 1, pp. 125-141.

[2] Dahlan, A., Nicol, M., \& Maciver, D. (2010). Elements of Life Satisfaction amongst Elderly People Living in Institutions in Malaysia: A Mixed Methodology Approach. Hong Kong Journal of Occupational Therapy 20 2, pp. 71-79.

[3] Haslina, M. (2006). The Applicability of the Big Five Inventory to the Malays. Dissertation of Masters Degree. Universiti Malaya.

[4] Khairudin, C.T. \& Jaafar, J. (2010). Religiositi dan Hubungan Positif dengan Orang Lain Sebagai Penyumbang Kepada Kebahagiaan Orang Melayu. Seminar Psikologi Kebangsaan. Universiti Malaysia Sabah.

[5] Olufadi, Y. (2016). Muslim Daily Religiosity Assessment Scale (MUDRAS): A New Instrument for Muslim Religiosity Research and Practice. Psychology of Religion and Spirituality 9 2, pp. $1-15$.

[6] Leslie J.F., Yaacov, B., Mandy, R. (2014). Religion and Happiness: A Study among Female Undergraduate Students in Israel. International Journal of Jewish Education Research 7 2, pp. 77-92.

[7] Joshanloo, M. (2013). Eastern Conceptualizations of Happiness: Fundamental Differences with Western Views. Journal of Happiness Studies 15 2, pp. 475-593.

[8] Attas, S. N. (1995). Prolegomena to the Metaphysics of Islam. Kuala Lumpur: International Institute of Islamic Thought and Civilization (ISTAC).

[9] Bayindir, A. (2003). Detailed Translation of the Quran: Surah the Opening and the Cow described. Istanbul: Suleymaniye Vakfi Yayinlari.

[10] Altiner, S. (2015). Happiness (Master's Thesis). University of Leiden: Theology and Religious Studies.

[11] Nasir, Y.A., Kahree, S. (2015). The Literature of Happiness: With reference of the Philosophy of Happiness in Islam. Journal of Islamic Studies and Culture 3 2, pp. 179-194.

[12] Al-Ghazali, Abu Hamid Muhammad. (1997). The Alchemy of Happiness. Trans: Hazrat Inayat Khan. New Delhi: Islamic Book Service.

[13] Ismail, Ibn Kathir. (2003). Tafsir Ibn Kathir (Abridged). Volume 1. Riyadh: Darussalam Publishers.

[14] Al-Ghazali, Abu Hamid Muhammad. (2001). Kimiya-I-Sa'adat (Alchemy of Happiness). Trans: Muhammad Asim Bilal. Lahore: Kazi Publications.

[15] Thomas, J.W. (2016). Emotional vs Rational Thinking. Are Assumptions Affecting Your Research? Quirks Marketing Research Review.

[16] Veenhoven, R. (2015). Condition of Happiness. Dordrecht: D. Reidel Publishing.

[17] Layous, K., Lee, H., Choi, I., Lyubomirsky. (2013). Culture Matters When Designing a Successful Happiness-Increasing Activity: A Comparison of the United States and South Korea. Journal of Cross-Cultural Psychology 44 8, pp. 1294-1303.

[18] Ojedokun, O., Balogun, S.K. (2013). Self-Monitoring and Responsible Environmental Behaviour: The Mediating Role of Attitude towards Littering. Frontiers in Psychologicaland Behavioral Science 2 1, pp. 31-38.

[19] Murata, S. (1992). The Tao of Islam: A Sourcebook on Gender Relationships in Islamic Thought. New York: State University of New York Press.

[20] Khatijah, O. (2015). EJBM-Special Issue: Islamic Management and Business: An Insightful Assessment on Customer Satisfaction from Contemporary and Islamic Perspective. Centre for Islamic Development Management Studies (ISDEV) Universiti Sains Malaysia, 7 16, pp. 3951.

[21] Abdul, G., Nurfaradilla, I. (2014). Happiness in Economics as Understood Across 'Ism and 


\section{Kresna Social Science and Humanities Research}

Proceedings of the International Conference On Ummah:

Digital Innovation, Humanities And Economy (ICU: DIHEc) 2020 https://doi.10.30874/ksshr.34

Religion. School of Economics, Universiti Kebangsaan Malaysia. 4 4, p.120.

[22] Abdul, R. (2004). The Book of Dhikr and Supplication in Accordance with the Accordance with the Quran and the Sunnah. Madinah: King Fahd Quran Printing Complex.

[23] Ruhul, S., Mohammad, Z.H., Nasser, A. (2016). Distribution of Wealth and Resources in Islam: Restoring Social Justice, Peace and Prosperity. International Journal of Economic Research 132 , pp. 571-586.

[24] Mohd, A.W., Suhaili, S., Asmuliadi, L. (2018). Authority Delegation in Organization: Lessons from 7th Century: Early Islamic Era. Jurnal al-Tamaddun, 13 1, p. 111.

[25] Omar S.H.S., Faisal M.N., Fadzli, A., Najihah, A.W., Rahimah, E., Othman, M.S., Abdullah S. (2017). Nature of Af'al According to Imam Al-Qushayri in the Book "At-Tahbir Fi At-Tazkir". International Journal of Academic Research in Business and Social Sciences 7 8, pp. 258-262.

[26] Layous, K., Lee, H., Choi, I., Lyubomirsky. (2013). Culture Matters When Designing a Successful Happiness-Increasing Activity: A Comparison of the United States and South Korea. Journal of Cross-Cultural Psychology 44 8, 1294-1303.

[27] Dalai, L., Howard, C. (2009). The Art of Happiness in a Troubled World. United Kingdom: Hodder \& Stoughton.

[28] Greco, C., Ison, M.S. (2014). What Makes You Happy? Appreciating the Reasons that Bring Happiness to Argentine Children Living in Vulnerable Social Contexts. Journal of Latino/ Latin American Studies 6 1, pp. 4-18.

[29] Stanca, L., Veenhoven, R. (2015). Consumption and Happiness: An Introduction. International Review of Economics 62 2, pp. 91-99.

[30] Diener, E. (2006). Guidelines for National Indicators of Subjective Well-being and Illbeing. Journal of Happiness Studies 7 4, pp. 397-404.

[31] Medvedev, O.N., Landhuis, C.E. (2018). Exploring Constructs of Well-being, Happiness and Quality of Life. , PeerJ, DOI 10.7717/peerj.4903.

[32] Talbott, T. (2013). Heaven and Hell in Christian Thought. Stanford University: Centre for the Study of Language Information. Retrieved from: www.plato.stanford.edu.my.

[33] Mattila, J. (2011). Philosophy as a Path to Happiness: Attainment of Happiness in Arabic Peripatetic and Ismaili Philosophy (Academic Dissertation). University of Helsinki.

[34] Omar S.H.S., Faisal M.N., Fadzli, A., Najihah, A.W., Rahimah, E., Othman, M.S., Abdullah S. (2017). Nature of Af'al According to Imam Al-Qushayri in the Book "At-Tahbir Fi At-Tazkir". International Journal of Academic Research in Business and Social Sciences 7 8, pp. 258-262.

[35] Al-Kirmani. (2007). Al-Ma'ab fi al-Ithbat al-Imamah. Walker, P. (ed.). Master of the Age: An Islamic treatise on the Necessity of the Imamate. London \& New York: I. B. Tauris.

[36] Mattila, J. (2011). Philosophy as a Path to Happiness: Attainment of Happiness in Arabic Peripatetic and Ismaili Philosophy (Academic Dissertation). University of Helsinki.

[37] Abdul, G., Nurfaradilla, I. (2014). Happiness in Economics as Understood Across 'Ism and Religion. School of Economics, Universiti Kebangsaan Malaysia. 4 4, p. 120.

[38] Steptoe, A. (2018). Happiness and Health. Annual Review of Public Health 12, 28 pp. 401-421.

[39] Nurdeng, D., Hayati, L. (2010). The Philosophy of Fasting in Preservation of Health: An Islamic Perspective. In Rabindarjeet, S., Ahmad, M. (Ed.), Fasting and Sustainable Health Conference, 2010 (pp. 139-144). Advanced Medical and Dental Institute, Universiti Sains Malaysia.

[40] Achour, M., Benaouda, B., Roslan, M. (2015). An Islamic Perspective on Coping with Life Stressors. Applied Research Quality Life, DOI 10.1007/s11482-015-93898.

[41] Ibrahim, D., Halil, E. (2018). Keep Calm and Be Happy: A Mixed Method Study from Character Strengths to Well-being. Educational Sciences: Theory and Practice, 18 2, pp. 303-354.

[42] Winzer, L., Samutachak, B., Gray, R.S. (2018). Religiosity, Spirituality, and Happiness in Thailand from the Perspective of Buddhism. Journal of Population and Social Studies 26, 4 pp. 332-343.

[43] Winzer, L., Samutachak, B., Gray, R.S. (2018). Religiosity, Spirituality, and Happiness in Thailand from the Perspective of Buddhism. Journal of Population and Social Studies 26 , 


\section{Kresna Social Science and Humanities Research}

Proceedings of the International Conference On Ummah:

Digital Innovation, Humanities And Economy (ICU: DIHEc) 2020

https://doi.10.30874/ksshr.34

pp. 332-343.

[44] Achour, M., Benaouda, B., Roslan, M. (2015). An Islamic Perspective on Coping with Life Stressors. Applied Research Quality Life, DOI 10.1007/s11482-015-93898.

[45] Ahuvia, A.C. (2008). Psychology and Economic Behaviour, United Kingdom: Cambridge University Press.

[46] Hudders, L., Pandelaere, M. (2012). The Silver Lining of Materialism: The Impact of Luxury Consumption on Subjective Well-Being. Journal of Happiness Studies 13 3, pp. 1-27.

[47] Hamermesh, D.S., Abrevaya, J. (2011). Beauty is the Promise of Happiness? University of Texas: Department of Economics.

[48] Abdul, G., Nurfaradilla, I. (2014). Happiness in Economics as Understood Across 'Ism and Religion. School of Economics, Universiti Kebangsaan Malaysia. 4 4, p. 120.

[49] Diener, E. (2019). Well-Being Interventions to Improve Societies. Global Happiness and Wellbeing Policy Report. USA: Global Council for Happiness and Wellbeing.

[50] Layous, K., Lee, H., Choi, I., Lyubomirsky. (2013). Culture Matters When Designing a Successful Happiness-Increasing Activity: A Comparison of the United States and South Korea. Journal of Cross-Cultural Psychology 448 p. 1294-1303.

[51] Dalai, L., Howard, C. (2009). The Art of Happiness in a Troubled World. United Kingdom: Hodder \& Stoughton.

[52] Budi, A., Djamaludin, A., Ratna, W. (2018). From Love to Family Happiness: A Theoretical Model for Javanese Family. European Journal of Social Science Education and Research 5 1, pp. 24-35.

[53] Layous, K., Lee, H., Choi, I., Lyubomirsky. (2013). Culture Matters When Designing a Successful Happiness-Increasing Activity: A Comparison of the United States and South Korea. Journal of Cross-Cultural Psychology 44 8, 1294-1303.

[54] Shah, H., Ramani, M., Gopal, A., Mukhopdyay, S. (2017). Spirituality and Happiness Among Youth: A Correlative Study. International Journal of Technical Research and Applications $\mathbf{5}$, 3:pp. 43-46.

[55] Nasir, Y.A., Kahree, S. (2015). The Literature of Happiness: With reference of the Philosophy of Happiness in Islam. Journal of Islamic Studies and Culture 3 2, pp. 179-194.

[56] Haris, K. M. (2012). Pandangan Islam Terhadap Tradisi dan Kemodenan. Jurnal Hadhari, 4 1, pp. 23-48.

[57] Ibn Qayyim, Muhammad. (2008). Miftah Dar al-Sa'adah wa Mansyur Wilayah al-Ilm wal Irada. Volume 1. Riyadh: Dar Ilm al-Fawaid.

[58] Lyubomirsky, S., Layous, K. (2013). How Do Simple Positive Activities Increase Wellbeing? Journal of Current Directions in Psychological Science 22 1, pp: 57-62.

[59] Kaldor, P., Hughes, P., Castle, K. \& Bellamy, J. (2004). Spirituality and Well-being in Australia. Sydney, Australia: NCLS Research. 